UDC 027.7:005.745

KOLESNYKOVA T. O.

Scientific and Technical Library, Dnipro National University of Railway Transport named after Academician V. Lazaryan (Dnipro, Ukraine), e-mail: chief.library@gmail.com, ORCID 0000-0002-4603-4375

\title{
CONFERENCE TIME IN THE LIBRARY AND INFORMATION SCIENCES. PART 1: CONFERENCE PROCEEDINGS AND PROCEEDINGS (CONFERENCE) PAPER
}

Objective. This study aims 1) to acquire new information on alternative conference formats, including in the field of Library and Information Science (LIS), which have arisen as a result of the COVID-19 pandemic and restrictions on physical communication; 2) to clarify the role of such a communication channel as Conference proceedings within the scientific ecosystem, as well as the concepts "proceedings paper" and "conference paper". Methods. Examining the new conference formats and special features of the Conference proceedings involved the content from the web-sites of international conferences in the field of LIS and related sciences, the analysis of subject-specific papers and data from the bibliographic and abstract databases such as Scopus and the Web of Science Core Collection (WoS). Results. It has been proven that over the year 2020 the online and hybrid events have become an alternative format of physical conferences. It has been confirmed that the Conference proceedings from the influential international conferences refer to the types of publications categorized as "high-quality papers". The peculiarity of LIS university researchers is that, in addition to studying problems focused only on the library activities, there is a need to conduct research into various subjects that are major for their institutions. Conference proceedings can be published as a book (a series of books), in a journal, or as a serial publication. Papers from them may be indexed by WoS (as "proceedings paper") and/or by Scopus (as "conference paper"); however, the impact factors of the publications themselves are not available in these databases. Conclusions. In the year 2020, the new pandemic reality, representing a circumstance of irresistible force, stimulated the flourishing of creative and technological solutions for online conferences. For international conferences, it is mandatory to publish the materials presented by their participants. Proceedings paper (conference paper) in journals are similar to standard journal articles in their structure but they have a less rigorous review process, they are published faster at a lower scientific impact (citation level).

Keywords: library and information science; virtual conference; hybrid conference; conference proceeding; proceedings paper; conference paper; university library; publication activity

\section{Introduction}

The current trend of publishing and presenting the most important research papers reporting studies' results indicates the preference given by authors and their institutions to the following three types of scientific media that publish "high-quality papers":

1. National journals with an international reputation

2. The best international journals generally recognized in the field of research

3. The best national and international conferences and their materials - conference proceedings.

There are no doubts that papers in journals indexed by (displayed in) international scientometric databases not only directly affect the university's ranking in a number of rating systems (Times Higher Education - THE, QS World University Rankings, Webometrics Ranking of World Universities, etc.), but also improve the transparency of results from university studies, and, consequently, their chance to be cited (Yurik, Lazarev, \& Skalaban, 2019). 
Until 2020, thousands of specialists annually gathered together to update their skills, expand the range of colleagues and areas of cooperation, learn about the latest developments and pilot projects in their scientific fields, including the library and information activities. At conferences, symposiums, seminars, and other meetings, participants present ideas and ways that could shape the future of research and implementation. In the context of this study, the correspondence conference format is not considered. The COVID-19 pandemic, as a circumstance of irresistible force that limited physical communication, had a serious impact on the scientific ecosystem, thereby forcing conference organizers and researchers around the world to devise an alternative that should facilitate scientific communication in these difficult times.

The currently devised alternative has been video conferencing using various software (Zoom, Microsoft Teams, MyOwnConference, Skype for business, etc.). As the past six months have shown, the personal digital presence of a large number of participants constantly encourages organizers to improve the technical capabilities of the conference and expand its reach, involving a much wider group of researchers in discussions. For example, the organizers of Virtual International Systems and Storage Conference (SYSTOR 2020) given the presence of participants in different time zones or lack of time at home, ask the authors to send a video of their speech long before the event. The video could be viewed by the conference participants. The organizers would broadcast the questions and answers live through the Slack system. After the conference, the videos would be uploaded to YouTube.

By building on the topic of new "pandemic" creative and technological solutions for online conferences, Simon Inger (2020) is justified to ask: "If one wants to properly push the global boundaries, why not make it possible for the speaker to speak in her/his own language and provide a translation? Especially if that language is the language of an army of online attendees one seeks to attract".

After all, it is important to remember that in today's time of dramatic uncertainties virtual conferences (local, regional, global) may be the only place and time when we have direct access to academic leaders, experts, and other professionals (Kolesnykova, 2020).

However, when a situation that is dangerous to people's health is resolved/improved, the physical and virtual meetings are not mutually exclusive (5th International Conference University Library at a New Stage of Social Communications Development, 2020). The blended conference or hybrid conference experience offers participants a safe, most effective and accessible way to meet and interact, physically or online (Information, Medium \& Society, 2020).

In essence, hybrid conferences are physical activities with embedded virtual elements to create an opportunity for participation by both those who can attend in person and those who can visit online. Moreover, the world scientific community is actively discussing "A theory of Zoom fatigue" (Sacasas, 2020). Video conferencing participants believe that many of them have had a physical, cognitive, and emotional tedious experience.

At the same time, at any format of an academic conference, the publication of materials presented by its participants remains unchanged and mandatory.

The bibliometric studies in the field of LIS help determine the publishing activity, visibility, impact, the scientific interaction of authors, as well as research trends (Jokić, 2020). The possibilities of the applications of the structure of bibliographical references in the proceedings of international scientific conferences for the management of information and library service are under discussion (Lazarev, Safonenko, \& Yunusova, 2001). 
The scientists in the field of LIS that examine the issues related to the place of LISpublications in the knowledge management process (Ahmad, JianMing, \& Rafi, 2019), note the insufficient activities by researchers. Thus, according to a study by N. K. Agarwal \& M. A. Islam (2018), the number of papers in the leading journals associated with LIS is very limited.

At the same time, when analyzing the papers included in the Library Assessment Conference (LAC) materials from 2006 to 2014, N. K. Dash, J. Sahoo \& B. Mohanty (2015) emphasize that the number of studies has been constantly increasing, with most of the papers written by one, two, or three authors, which is approximately $40 \%, 33 \%$, and $15 \%$, respectively.

However, personal observations show that we still lack an understanding of how important the papers from the world's, interregional, and regional LIS leading conferences are, what appears to be a distinctive culture of publications; this requires more detailed study.

From my point of view, scientists and practitioners in the field of library and information science, while being aware of the need to integrate into the world's scientific and educational space to open the achievements of their universities to the world, do not always understand the importance and features of conference proceedings as one of the main channels of academic communication.

\begin{abstract}
Aims
This study aims: 1) to acquire new information on alternative formats of conferences, including in the field of Library and Information Science (LIS), resulting from the COVID-19 pandemic and restrictions on physical communication; 2) to clarify the role of such a communication channel in the scientific ecosystem as Conference proceeding, as well as the concepts of "proceedings paper" and "conference paper".
\end{abstract}

\title{
Methods
}

Various research methods were used in this study. Thus, some data were acquired by the method of internal and external observation, describing the self-reflection of my own experience as a chairman of the organizing committee of the annual international conference "University Library at a new stage of social communications development" (http://conflib.diit.edu.ua/Conf_univ_Library2020) and the editor of the journal "University Library at a new stage of social communications development. Conference proceedings" (http://unilibnsd.diit.edu.ua).

To study the state of scientific development, the content from the web-sites of international conferences in the field of LIS and related sciences was analyzed, as well as the subject-specific publications on the topic of this work. In the context of the current study, particular attention was paid to conference proceedings - papers and reports that are peerreviewed publications available for searching in bibliographic databases (including via DOI). The abstracts or reports of papers compiled by researchers at conferences were not considered in this study.

The conference web-sites were identified by applying the Google and Google Scholar search engines using the keywords "LIS conference*", "conference proceeding" and "university librar*". The chronological framework was confined to 2020. Language was not specified.

In order to clarify the features of conference proceedings, the concepts, types, forms of presentation, the availability/absence of metrics of the publication, features of structuring, and 
the quality of conference documents ("proceedings paper" or "conference paper") were determined.

To better understand the role of such a channel as conference proceeding in scientific communications, the state of publishing activities by the library and information science specialists presenting their papers at conferences was considered. However, for a general idea of how conference proceedings fit into the overall research pattern, I have investigated other fields of science.

The application of mixed methods in this paper, in my point of view, can help determine the trends and areas in LIS research. The results could prove relevant to future research and decision-making.

\section{Results}

The analysis of data proves that such a channel of scientific communication as conferences is widely represented in the field of Library and Information Science around the world. When contacting professional web-sites, it was established that the most significant are those that have the regional, interregional, or international reach of participants. For example, the website of the Ukrainian Library Association (ULA) (https://ula.org.ua/konferentsii-seminarytreninhy/konferentsii/cat.listevents/2019/04/16/).provides information about 10 conferences at different levels in 2020.

The European Bureau of Library, Information, and Documentation Associations (EBLIDA) (http://www.eblida.org/about-eblida/council/conferences/) provides a platform for the communication of Europe's librarians. A great opportunity to learn about the latest initiatives from academic libraries in different countries, as well as meet colleagues and friends from all over the world is annually given at conferences of the International Association of University Libraries (IATUL) (https://www.iatul.org/events/annual-conference).

The Asian-Pacific region is represented by its LIS-forums at the web-site "Library conferences in Asia 2020-2021" (https://librarylearningspace.com/keep-up-to-date-with-whatshappening-in-libraries-in-the-region/). Global information is provided by the digital resource "International Library Related Conferences. List", compiled and maintained by James Thull (Montana State University Library) and Marian Dworaczek (University of Saskatchewan Library) (Thull \& Dworaczek, 2020) showcasing around 100 conferences (conventional and online) to be held from March 2020 to June 2027 (as of March 17, 2020).

The situation with the COVID-19 pandemic has forced conference organizers from all areas of knowledge to take one of the following solutions:

1) Translation of a scientific event into an online format. For example, Chartered Institute for Library and Information Professionals (CILIP) Copyright Conference 2020 - London, UK (https://www.cilip.org.uk/page/CopyrightConf20); EBLIDA 2020, Annual Council Meeting and Conference (http://www.eblida.org/about-eblida/council/conferences/); Library Publishing Forum 2020 - Atlanta, Georgia. USA (https://librarypublishing.org/forum/);

2) Postponing the event to a later date. For example, International Conference on Web Research (http://iranwebconf.ir/) and Eurasian Academic Libraries Conference - 2020 (https://nu.kz.libguides.com/EALC-2020);

3) Consolidation of conferences 2020 and 2021. For example, HUMANIST conference 2020-2021 (Rhodes, https://www.humanist-vce.eu/major-activities/conference/rhodes-2020/);

4) Cancellation of the conference this year. For example, ALIA (Australian Library and Information Association) National 2020 Conference (https://www.alia.org.au/events/ 17945/alia- 
national-2020-conference); Evidence Based Library and Information Practice Conference (Canada, https://www.eblip10.org/); Libraries in the Digital Age (LIDA) conference 2020 (InterUniversity Centre, Dubrovnik, Croatia, http://lida.ffos.hr/); 41st IATUL Annual Conference Bridging Universities and Society Libraries as Connectors (https://www.iatul.org/events/annualconference); IFLA World Library and Information Congress 2020 (https://www.ifla.org/node/92996). Sometimes, at the same time, presentations, annotations and / or publications of works are still presented on conference sites (this mainly concerns the fields of computer technology and engineering, where publication of works is as important as journal articles). For example, 20th European Conference on Cyber Warfare and Security (https://www.academic-conferences.org/conferences/eccws/).

In academia, including the field of library and information science, summing up a conference (physical or online) implies a collection of papers published within the framework of an academic conference or seminar, including reports, abstracts, or summary on the reports submitted by participants. In the context of the current study, conference proceedings are the reports presented by researchers at a conference. They are a written recording of the work, which is submitted to fellow researchers and is typically distributed in a print/electronic form either before the launch of the conference or after it is closed (Conference proceeding, 2020). At the same time, while revealing new trends and concepts almost immediately after their emergence and study, published works do not always have a continuation in the form of an extended paper in influential scientific journals and are registered only as a conference document (proceedings papers or conference papers). J. Kim's study (2019) proves that most computer scientists tend to debut in scientific research, publish more articles, and collaborate with more co-authors at conferences rather than via journals.

Conference proceedings can be published as a book or a series of books, a journal or otherwise as a serial publication (Conference proceeding, 2020).

Accordingly, their bibliographic description differs. Thus, the Referencing and Citation Styles: APA 6th edition (2009) notes that "Conference papers can be published in book or periodical form, or online. To cite published proceedings from a book, use the same format as for a book or a book chapter (excepting that the book title is capitalized - as it is the name of a conference). To cite proceedings that are published regularly, use the same format as for a journal".

For example,

Published in a book:

Armstrong, D. B., Fogarty, G. J., \& Dingsdag, D. (2007). Scales measuring characteristics of small business information systems. In W-G. Tan (Ed.), Proceedings of Research, Relevance and Rigour: Coming of age: 18th Australasian Conference on Information Systems (pp. 163-171). Toowoomba, Australia: University of Southern Queensland. Retrieved from https://www.semanticscholar.org/paper/Scales-measuring-characteristicsof-small-systems-Armstrong-Fogarty/e03fac8ae93f63f4b1b7d8810361758fbd65b289.

Published in a journal:

Kolesnykova, T. (2019). The Role of Libraries as Publishers in the Open Education Landscape: Reflecting Modern World Practice of Open Textbooks. University Library at a New Stage of Social Communications Development. Conference Proceedings, 4, UniLibNSD2019, 88-99. DOI: http://dx.doi.org/10.15802/unilib/2019_187423

If a publication has a Digital Object Identifier (DOI) listed, you will always include this identifier in your reference. This will replace the need to include the URL of the journal's home 
page. Refer to the Additional information box to the right for help in locating DOIs, whether they are, or are not, included with the publication.

In addition, different types of publications may refer to different study areas.

Thus, the "conference proceedings" published in books have long been known as a popular way of scientific communication in the physical and engineering sciences. However, in the fast-growing fields of biomedical sciences, proceedings are more often published in journals. In life sciences, for example, the rapid dissemination of critical information is of paramount importance, and journals provide the best way to do so (Thomson Reuters, 2008). For example, "Integrative Journal of Conference Proceedings" (https://crimsonpublishers.com/icp) or "BMC Proceedings" (https://bmcproc.biomedcentral.com/).

At the same time, the rapidly developing areas also include computer and information sciences, as well as energy engineering, materials science, etc., so conference papers published in journals are steadily gaining importance. The examples are the "European Physical Journal Web of Conferences" (https://epjwoc.epj.org/epjwoc-aims-and-scope), "Procedia Manufacturing" (https://www.journals.elsevier.com/procedia-manufacturing), "Proceedings. MDPI" (https://www.mdpi.com/journal/proceedings), "Materials Today: Proceedings" (https://www.journals.elsevier.com/materials-today-proceedings ).

Although conference proceedings may be indexed by WoS / Scopus as peer-reviewed journals within a "journal" category (Jokić, 2020), or as "Conference Proceeding" or "Book Series", their impact factors are not provided by these databases (IOPScience, 2020). However, given the indexing, one can monitor the impact of a paper/conference paper, the authors, as well as conference series.

One general pattern is that conference documents become obsolete (thereby stopping to attract new citations) much earlier than journal articles (Lisée, Larivière, \& Archambault, 2008), a possible reason being the conferences' focus on rapidly changing topics.

At the same time, there may exist other metrics for conference proceedings such as h-index by Google Scholar and the metric by Scimago (https://www.scimagojr.com/ journalsearch.php?q=26916\&tip=sid); Figure 1. The metric by Scimago.

Bibliographic indexing is often provided by individual bibliographic databases and citation indexes, such as Web of Science: Conference Proceedings Citation - CPCI (Web of Science ${ }^{\mathrm{TM}}$ Core Collection, Clarivate Analytics, 2020) instead of Science Citation Index.

In 2008, a new type of document, the "proceedings paper" (PP), was selected in the WoS database, assigned to papers that were originally submitted to a conference and then adapted for publication in a journal. And since then, the WoS use of two different tags, "article" and "proceedings paper", as well as "article" and "conference paper" in the Scopus database, has constantly led to discussions about differences in their relevance and/or quality. (González-Albo, \& Bordons, 2011; Kim, 2018). 


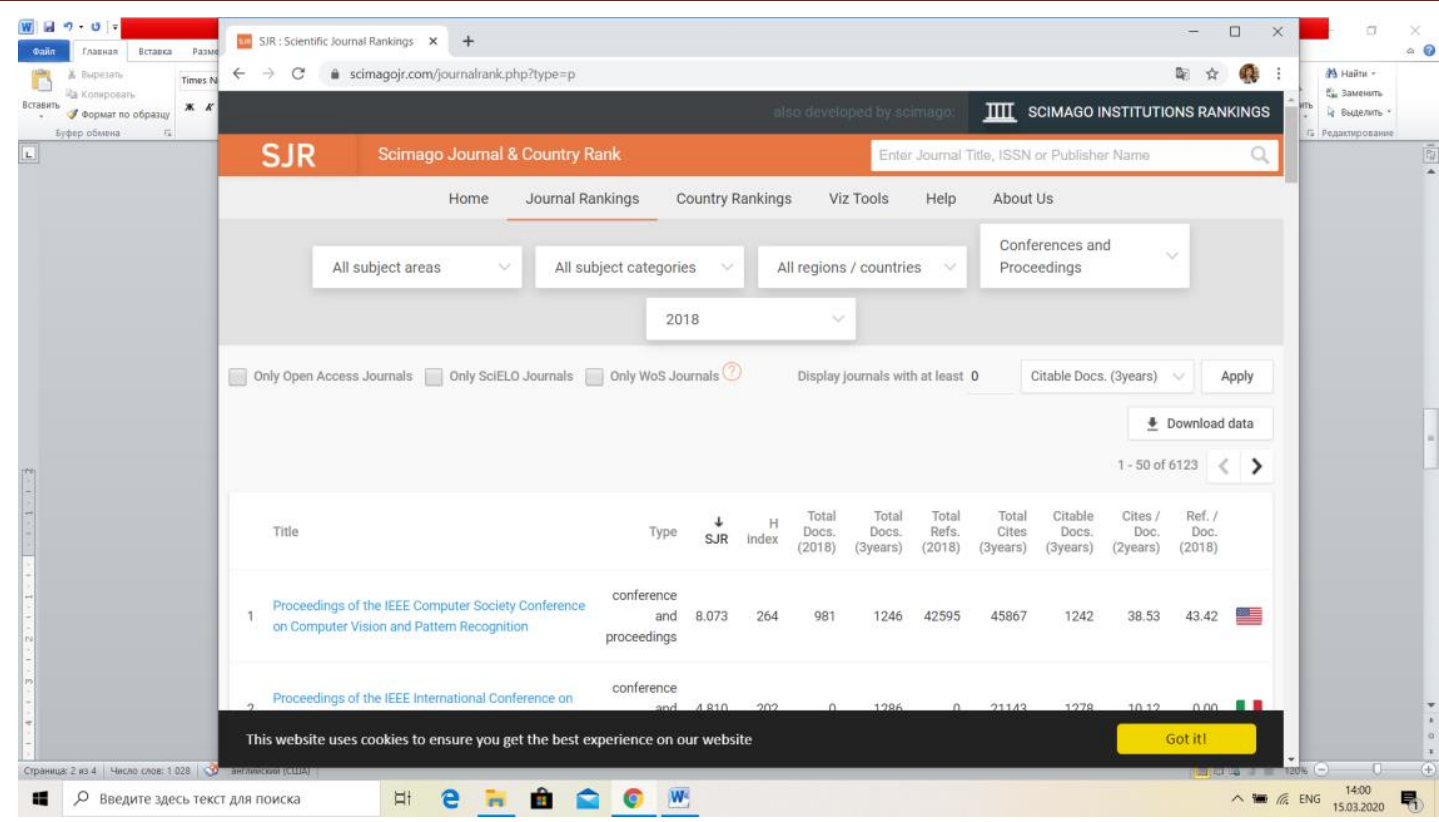

Figure 1. The metric by Scimago

The quality of international conference papers is usually assessed by outside experts. The level of quality control varies greatly from conference to conference: some editorial teams make only a binary decision about accepting/rejecting a document, while others organize a thorough feedback cycle to update (review) documents. Depending on the level of the conference, this process can take up to a year (Proceedings, 2020). The leading conferences, whose materials are indexed by Scopus and Web of Science, have a rather low manuscript acceptance factor (about $30 \%)$.

Arguing about the peculiarities of structuring and writing papers for journals and conference materials, A. Jain, N. S. Bhandari, N. Jain (2018) emphasize the importance of compliance with a standard form, language, and style of research work that facilitates their reading and perception by readers and colleagues (Jain, Bhandari, \& Jain, 2018). The authors clarify the role of each of the main elements in an article and conference paper in the social, IT, and other sciences, namely: Title, Abstract, Introduction, Methods, Problem Statement, Review of Literature, Formulating a Hypothesis, Results, and Discussions.

The case study by Borja González-Albo \& María Bordons (2011) in the field of Library and Information Science aims to study the potential differences between standard journal articles and proceedings papers in journals, based on the Web of Science data. One finding shows that "proceedings paper in journals" are similar to "standard journal articles" in structure but they have a less rigorous review process, they are published faster, they demonstrate a lower impact (citation level).

The peculiarity of university LIS researchers should be emphasized. In addition to conducting research focused only on the library activities, there is a need to conduct research in various disciplines relevant to their institutions (Borrego, Ardanuy, \& Urbano, 2018; Kolesnykova, Matveyeva, Manashkin, \& Mìshchenko, 2019; Lazarev, 2019; Dash, Sahoo, \& Mohanty, 2015). At the same time, scientific cooperation among lecturers and scientists, yielding the co-authorship of scientific results, is one of the possible ways to demonstrate the correspondence of a library to the institution's mission. 
To study conference materials reflecting various aspects of university library research, the Scopus and Web of Science databases were used, which started indexing conference materials for citation counting around the mid-2000s (De Sutter, \& Van Den Oord, 2012).

This issue will be discussed in more detail in the second part of the study "Conference time in the library and information sciences. Part 2: Bibliometric analysis of the publication activity".

\section{Conclusions}

The high-quality higher education, backed by research at the university level, is a key factor in the further development of any part of a knowledge-based global society. University librarians consistently demonstrate their importance for their home institutions, including in providing research support services. The scientific collaboration between librarians, lecturers, and scientists, which yields the co-authorship of scientific results, is one possible way to demonstrate that a library is consistent with the university's mission. Thus, librarians as authors contribute to the development not only of library and information sciences (LIS) but also of various disciplines that are major for their institutions.

In this case, a reliable and fast channel of scientific communication is the participation of LIS researchers in influential conferences at different levels providing the publication of works in conference proceedings. The most significant in the scientific ecosystem are those proceedings whose papers are indexed by WoS (as "proceedings paper") and/or by Scopus (as "conference paper").

The value of the Conference proceeding lies in the following facts:

1. This format helps authors of primary research in rapidly developing fields of science to get their research work to the global community faster than traditional journals.

2. Provision of reports on scientific meetings and obtaining snapshots of early-stage research that may later appear in full research papers.

3. For scientists just beginning their careers, the papers offer what may be their first experience in publishing peer-reviewed works.

4. Small scientific communities and scientists of those countries that currently have a low publication and impact level in international scientific journals.

5. Most conferences use only one (or two) review/revision cycles due to deadlines, which is a softer variant than traditional journals.

6 . They give an incentive for personal growth and help to overcome the psychological barrier for those researchers who are recognized scientists in their countries/regions, but did not have the incentive and opportunity to publish in foreign journals/conference proceedings because of the country's internal politics.

7. Conference proceeding papers, like journal articles and other types of publications, also form an important scientific field in which bibliometric tools can be used to evaluate various outcomes, through which it has attracted the attention of scholars in various disciplines.

At the same time, LIS scientists studying the place of LIS publications in the knowledge management process note the lack of activity by researchers.

The new pandemic reality, as a circumstance of irresistible force leading to physical distancing, has stimulated the flourishing of creative and technological solutions for online and hybrid conferences, including in the field of LIS. 


\section{REFERENCES}

Agarwal, N. K. \& Islam, M. A. (2018). Ascertaining the place of Library \& Information Science in Knowledge Management research. Proceedings of the 81st Annual Meeting of the Association for Information Science \& Technology, Vancouver, Canada, November 9-14, 2018. doi: https://doi.org/10.1002/pra2.2018.14505501002 (in English)

Ahmad, K., JianMing, Z, \& Rafi, M. (2019). Assessing the literature of knowledge management (KM) in the field of library and information science. Information Discovery and Delivery, 47(1), 35-41. doi: https://doi.org/10.1108/IDD-06-2018-0021 (in English)

Armstrong, D. B., Fogarty, G. J., \& Dingsdag, D. (2007). Scales measuring characteristics of small business information systems. In W-G. Tan (Ed.). Proceedings of Research, Relevance and Rigour: Coming of age: 18th Australasian Conference on Information Systems (pp. 163-171). Toowoomba, Australia: University of Southern Queensland. Retrieved from https://www.semanticscholar.org/paper/Scales-measuring-characteristics-of-small-systemsArmstrong-Fogarty/e03fac8ae93f63f4b1b7d8810361758fbd65b289 (in English)

Borrego, A., Ardanuy, J., \& Urbano, C. (2018). Librarians as Research Partners: Their Contribution to the Scholarly Endeavour Beyond. Library and Information Science, 44(5), 663-670. doi: https://doi.org/10.1016/j.acalib.2018.07.012 (in English)

Conference proceeding. (2020). Wikipedia, The Free Encyclopedia. Retrieved from https://en.wikipedia.org/wiki/Conference proceeding (in English)

Dash, N. K., Sahoo, J., \& Mohanty, B. (2015). Evolution of Library Assessment Literature - A Bibliometric Analysis of LAC Proceedings. Innovative Librarianship: Adapting to Digital Realitiesin Proceedings of 10th International CALIBER -2015, March 12-14, HP University, IIAS, Shimla and INFLIBNET Centre, Himachal Pradesh, India, 91-106. Retrieved from https://www.researchgate.net/publication/275644489__Evolution_of_Library_Assessment_Literat ure_-_A_Bibliometric_Analysis_of_LAC_Proceedings (in English)

De Sutter, B., \& Van Den Oord, A. (2012). To be or not to be cited in computer science. Communcations of the ACM, 55(8), 6975. Retrieved from

https://www.researchgate.net/publication/236162772 To Be or not to Be Cited in Computer _Science (in English)

González-Albo, B., \& Bordons, M. (2011). Articles vs. proceedings papers: Do they differ in research relevance and impact? A case study in the Library and Information Science field. Journal of Informetrics, 5(3), 369-381. doi: https://doi.org/10.1016/j.joi.2011.01.011 (in English)

Information, Medium \& Society (2021). International Conference on Publishing Studies. Retrieved from https://informationmediumsociety.com/2021-conference (in English)

Inger, S. (2020). Pivoting your Conference: Pandemic as the Mother of Invention. The Scholarly Kitchen. Retrieved from https://scholarlykitchen.sspnet.org/2020/07/07/pivoting-your-conferencepandemic-as-the-mother-of-invention/?informz=1 (in English)

IOPScience. (2020). Proceedings policy on Impact Factors. Retrieved from https://publishingsupport.iopscience.iop.org/questions/proceedings-policy-on-impact-factor/ (in English)

Jain, A., Bhandari, N. S., \& Jain, N. (2018). Essential Elements of Writing a Research/Review Paper for Conference/Journals. IEEE 5th International Symposium on Emerging Trends and Technologies in Libraries and Information Services (ETTLIS); 21-23 February 2018, 131-136. doi: https://doi.org/10.1109/ETTLIS.2018.8485210 (in English) 
Jokić, M. (2020). Productivity, visibility, authorship, and collaboration in library and information science journals: Central and Eastern European authors. Scientometrics. 122(2), 1189-1219. doi: https://doi.org/10.1007/s11192-019-03308-4 (in English)

Kim, J. (2019). Author-Based Analysis of Conference versus Journal Publication in Computer Science. Journal of the Association for Information Science and Technology, 70(1), 71-82. doi: https://doi.org/10.1002/asi.24079 (in English)

Kolesnykova, T. (2019). The Role of Libraries as Publishers in the Open Education Landscape: Reflecting Modern World Practice of Open Textbooks. University Library at a new stage of social communications development. Conference proceedings, 4, 88-99. doi: http://dx.doi.org/10.15802/unilib/2019_187423 (in English)

Kolesnykova, T. (2020, May 29). Yak orhanizuvaty viddalenu robotu kolektyvu universytetskoi biblioteky v umovakh nevyznachenosti? [How to organize remote work of the university library staff in conditions of uncertainty?] [Video file]. Retrieved from https://www.youtube.com/watch?v=LxAZNHs3SyU\&fbclid=IwAR3XRUqLHle1PY-6tdP1nT0vH1t6OgeGUlFf0FumwLWDUChBgmzy75Q0SI (in Ukranian)

Kolesnykova, T., Matveyeva, O., Manashkin, L., \& Mìshchenko, M. (2019). Railway transportation of dangerous goods: a bibliometric aspect. MATEC Web of Conferences 294, 03014. EOT-2019. doi: https://doi.org/10.1051/matecconf/201929403014 (in English)

Lazarev, V. S., Safonenko, D. A., Yunusova, D. A. (2001). Bibliometric research of international scientific conferences proceedings in the context of current objectives of library and information service. Journal of Interlibrary Loan, Document Delivery and Information Supply, 11(4), 103$118 . \quad$ Retrieved from https://www.researchgate.net/publication/254380484_Bibliometric_Research_of_International_S cientific Conferences Proceedings in the Context of the Current Objectives of Library and Information Service (in English)

Lazarev, V. (2019). On the Possibilities of Evaluating Properties of Scientific Documents on the Basis of their Citations Count (or again: What Property is Reflected by Citations Count par excellence, after all?). Part 1: Value. University Library at a new stage of social communications $\begin{array}{lllll}\text { development. } \quad \text { Conference } & \text { proceedings, } & \text { 4, } 36 . & \text { doi: }\end{array}$ http://dx.doi.org/10.15802/unilib/2019 187405 (in English)

Lisée, C., Larivière, V., \& Archambault, E. (2008). Conference proceedings as a source of scientific information: A bibliometric analysis. Journal of the American Society for Information Science and Technology, 59(11), 1776-1784. Retrieved from https://www.researchgate.net/publication/220432712 Conference proceedings as a source of s cientific information A bibliometric analysis (in English)

Proceedings. (2020). Wikipedia, The Free Encyclopedia. Retrieved from https://en.wikipedia.org/wiki/Proceedings (in English)

Referencing and Citation Styles: APA 6th editions. (2009). Retrieved from https://libguides.scu.edu.au/apa6/conference-papers/proceedings (in English)

Sacasas, L. M. (2020, April 21). A Theory of Zoom Fatigue. The Convivial Society: Dispatch, 5. Retrieved from https://theconvivialsociety.substack.com/p/a-theory-of-zoom-fatigue (in English)

Thomson Reuters. (2008). White Paper conference proceedings and their impact on global research. Enhancing proceedings coverage with cited reference searching. Retrieved from http://wokinfo.com/media/pdf/proceedingswhtpaper.pdf (in English)

Thull, J., \& Dworaczek, M. (2020). International Library Related Conferences: List. Retrieved from http://www.lib.montana.edu/ james/ (in English) 
University Library at a New Stage of Social Communications Development. Conference Proceedings. (2020). Retrieved from http://unilibnsd.diit.edu.ua (in English)

Yurik, I., Lazarev, V., \& Skalaban, A. (2019). Role of Bibliometric Evaluation of Scientific Journals in Maintaining the Ranking of the University. Menedzhment vuzovskih bibliotek. Otkrytaya nauka: praktiki i modeli sotrudnichestva : materialy XIX Mezhdunar. konf., Minsk, 30-31 oct. 2019. Belarusian National Technical University, 81-92. Retrieved from https://rep.bntu.by/handle/data/68490 (in English)

Web of Science. Clarivate. (2020). Web of Science: Conference Proceedings Citation Index. Retrieved from https://clarivate.com/webofsciencegroup/solutions/webofscience-cpci/ (in English)

5th International Conference University Library at a New Stage of Social Communications Development, Dnipro, Ukraine, 8-9 October, 2020. Retrieved from http://conflib.diit.edu.ua/Conf_univ_Library2020 (in English)

\section{Links}

BMC Proceedings. Retrieved from https://bmcproc.biomedcentral.com/

European Bureau of Library, Information and Documentation Associations (EBLIDA). http://www.eblida.org/about-eblida/council/conferences/

European Physical Journal Web of Conferences. Retrieved from https://epjwoc.epj.org/epjwoc-aims-and$\underline{\text { scope }}$

IATUL Annual Conference. Retrieved from https://www.iatul.org/events/annual-conference

Integrative Journal of Conference Proceedings. Retrieved from https://crimsonpublishers.com/icp

Library conferences in Asia 2020-2021. Web-site. Retrieved from https://librarylearningspace.com/keepup-to-date-with-whats-happening-in-libraries-in-the-region/

Materials Today: Proceedings. Retrieved from https://www.journals.elsevier.com/materials-todayproceedings

Procedia Manufacturing. Retrieved from https://www.journals.elsevier.com/procedia-manufacturing

Proceedings MDPI. Retrieved from https://www.mdpi.com/journal/proceedings

The International Association of University Libraries (IATUL). Retrieved from https://www.iatul.org/events/annual-conference

Ukrainian Library Association (ULA). Website of the ULA. https://ula.org.ua/konferentsii-seminarytreninhy/konferentsii/cat.listevents/2019/04/16/

University Library at a new stage of social communications development: International Conference. Retrieved from http://conflib.diit.edu.ua/Conf_univ_Library2020

Virtual International Systems and Storage Conference (SYSTOR) 2020, Haifa, Israel. Retrieved from https://www.systor.org/2020/\# 
КОЛЕСНИКОВА Т. О.

Науково-технічна бібліотека, Дніпровський національний університет залізничного

транспорту імені академіка В. Лазаряна (Дніпро, Україна),

e-mail: chief.library@gmail.com, ORCID 0000-0002-4603-4375

\section{ЧАС КОНФЕРЕНЦЙ В БІБЛІОТЕЧНО-ІНФОРМАЦЙНИХ НАУКАХ. YAСТИНA 1: CONFERENCE PROCEEDINGS TA PROCEEDINGS (CONFERENCE) PAPER}

Мета. В рамках даного дослідження передбачається: 1) отримати нову інформацію про альтернативні формати конференцій, в т.ч в області Library and Information Science (LIS), що виникли в результаті пандемії COVID-19 та обмеження фізичного спілкування; 2) уточнити роль в науковій екосистемі такого каналу комунікації як Conference proceeding, а також понять "proceedings paper" i "conference paper". Методика. Розгляд нових форматів конференцій та особливостей Conference proceedings передбачало звернення до контенту сайтів міжнародних конференцій в області LIS і суміжних наук, аналіз профільних публікацій із теми роботи та даних бібліографічних і реферативних баз Scopus i Web of Science Core Collection (WoS). Результати. Доведено, що в 2020 р. альтернативними форматами фізичних конференцій стали онлайн і гібридні. Підтверджено, що Conference proceeding впливових міжнародних конференцій відносяться до типів видань, що публікують "high-quality papers" (високоякісні документи). Особливість університетських дослідників LIS у тому, що крім вивчення проблем, сфокусованих тільки на бібліотечну справу, існує необхідність проведення досліджень у різних дисциплінах, профільних для їх інституцій. Conference proceedings можуть бути опубліковані у вигляді книги (серії книг), журналу чи іншим чином у вигляді серійного видання. Статті з них можуть індексуватися в WoS (як "proceedings paper") i / aбо в Scopus (як "conference paper"), але фактори впливу самих видань в цих базах недоступні. Висновки. 2020 рік і нова пандемічна реальність, як обставина непереборної сили, стимулювали розквіт творчих і технологічних рішень для онлайн-конференцій. Для міжнародних конференцій обов'язковим є опублікування матеріалів, презентованих іiі учасниками. Proceedings paper (conference paper) в журналах (in journals) аналогічні standard journal articles за структурою, проте вони відрізняються менш суворим процесом рецензування, швидшим опублікуванням та більш низьким науковим впливом (рівнем цитування).

Ключові слова: Library and Information Science; віртуальна конференція; гібридна конференція; Conference proceeding; proceedings paper; conference paper; університетська бібліотека; публікаційна активність 